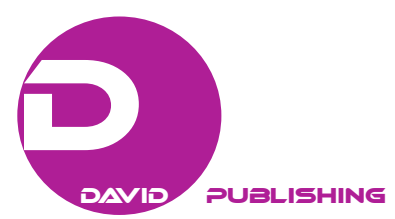

\title{
The July 15 Coup Attempt in Turkey and the Hypocricy of the West
}

\author{
Hanefi Yazic1 \\ Bandırma Onyedi Eylül University, Bandırma, Balıkesir, Turkey
}

\begin{abstract}
As well known, Turkey's political history is the history of coups. However, the July 15 coup attempt is really different from the coups of 1960, 1971, 1980, and 1997. It was the first time that the Junta opened fire against the people in the streets. On July 15, the members of Fethullah Gulen Terorist Organisation (FETO) tried to overthrow the Turkish government. Many institutions in Turkey such as the Grand National Assembly (TBMM) and television channels were bombed. Moreover, in Istanbul both of the bridges and airports were shut down by tanks. In addition, the FETO members tried to assassinate President Erdoğan. Therefore it is vital to examine the July 15 coup attempt and its backgrounds.
\end{abstract}

Keywords: FETO, coup, junta, Erdogan, Turkish Government, terorist organization

\section{Introduction}

The army has seen itself as the guardian of secular regime in Turkey for a long time. Therefore, it has intervened three times in Turkish politics, and in 1997 it was described as a postmodern coup. The first coup took place in 1960 (Oran, 2009). The military began to make plans for the coup when the Prime Minister Menderes changed the call to prayer in Arabic instead of Turkish. Finally, on May 27, Menderes and his friends were hanged. The coup tradition of the army in Turkey continued in 1971. The military intervened once again giving a memorandum to the Prime Minister Demirel because of the financial problems and Demirel had to resign after the memorandum of the military. The military did not rule directly during this period and Nihat Erim formed a caretaker government.

Instability continued even after the 1971 coup. Turkey changed governments every year in the 1970 s and left-and-right-wing groups continued their violent clashes in the streets. Thousands of people were assassinated. Finally, the military imposed martial law and dissolved the government in 1980. Evren became president, and the military arrested thousands of people and also hundreds of people were executed, tortured, or disappeared.

In 1997 the military issued a series of recommendations, the Prime Minister Erbakan agreed to a compulsory eight-year education programme, a headscarf ban at universities, and other measures. Erbakan was forced to resign, his party was shut down, and he was banned from politics for five years. In the February 28

Hanefi Yazıc1, Ph.D., associate professor, Department of Political Sciences and International Relations, Faculty of Economics and Administration Sciences, Bandırma Onyedi Eylül University Balıkesir, Turkey.

Correspondence concerning this article should be addressed to Hanefi Yazıc1, Department of Political Sciences and International Relations, Faculty of Economics and Administration Sciences, Bandırma Onyedi Eylül University, Balıkesir, Turkey. 
memorandum, the media were used and manipulated, that's why it was described as a postmodern coup. The military changed the coup method in 2007 and posed an ultimatum on its website to warn Erdogan for presidential elections. It was the first time in Turkish political history that the government authorities made counter-statements reminding the true place of the army.

\section{FETO Coup and Erdogan's Leadership}

On Friday evening, FETO members took Ataturk Airport, two bridges over the Bosphorus and TV channels, including TRT and CNN-Turk, under control. President Erdogan was on holiday when the military tried to take over the country. He first called Turkish people to the streets to protect the country for their freedom and independence. Unfortunately, more than two hundred people were killed by FETO members and hundreds of people were injured. The call of Erdogan was enough to make people take to the streets filling up city centers and the ordinary people resisted the coup at the cost of their lives.

It is obvious that the popular resistance against the coup is a significant factor in terms of resisting the coup attempt. The Junta assumed that secular, leftist, and nationalist citizens would support the coup. However, on July 15, just after the call of Erdogan, millions of people started to march in the streets leaving aside their differences to protect their country despite the bullets and the F-16 jets flying over their heads. Therefore, the courageous people who sealed the fate of Turkey were recorded in history since they defended their country by standing up against the tanks.

Fabricated news about Turkey has made the headlines many times in Western media as in FETO Coup. Foreign media started to spread news that the military had taken control of the government. Unfortunately, Western media began to accuse Erdoğan and tried to portray him as responsible for these events. Western media presented FETO as a peaceful face of Islam and the US still continue to keep its leader considering Turkey as a Third World country. It is obvious that some political strategists like Graham Fuller, the CIA's former chief for Turkey, who describes the Gulen movement as a moderate face of Islam even after the July 15 coup attempt really have a deep effect on the US politicians.

\section{FETO Coup and Western Media}

Before the July 15 coup, some articles reminding readers of a possible and acceptable coup in Turkey were published in the Western media. For instance, an article entitled "Turkey's Next Military Coup" was published at Foreign Affairs by Gonul Tol on May 30, 2016, and another article pointing a convenient ground for a coup in Turkey was published at the American Enterprise Institute by Michael Rubin on March, 2016. Rubin asks in his shameful article whether there will be a coup against Erdogan in Turkey claiming that the situation in Turkey is bad and getting worse. According to him, Turks and the Turkish military increasingly recognize that Erdoğan is taking Turkey to the precipice. He states that in election season, it is doubtful that the Obama administration would do more than criticize any coup leaders. He assumes that when Morsi was ousted, his commitment to democracy was still subject to debate and for Erdogan the same would happen. He believes that the U.S. governments might offer lip service against a coup, but they would work with the new regime. He threatens Erdogan as if he might find himself like Saddam Hussein at his own trial. He even offers the Turkish military to imitate Sisi's plan in Egypt for Erdogan. It was the same during the Gezi Park protests, Western media, particularly CNN, took the side of the protesters for a government change in Turkey. In addition, BBC producer James Bryant looked for someone who would criticize the governments' actions (BBC). 
As for the July 15 coup, the attitude of the Western media continued as usual, they spoke of the coup as a power struggle between two sides placing Erdogan on one side as a symbol of authoritarianism and the military junta on the other as a symbol modernization. The articles and news that appeared in the Wall Street Journal and the Washington Post tried to justify the coup attempt. Articles published on the July 15 coup attempt argued that a military coup in Turkey would be better for the West. In general, they chose to side with the military junta and when it became evident that the coup attempt failed, they began to manipulate that Turkey will become more authoritarian after the coup attempt. Perhaps, due to the manipulations of the Western media, anti-Americanism and Western opposition will be on the rise in Turkey.

During the coup in Turkey, not surprisingly Fox News Strategic Analyst Ralph Peters praised the coup in Turkey. He said that the people staging the coup are the good guys and added that God bless the people trying to stage the coup. Peters conducted an interview with Gulen and highlighted that Gulen had no ties with the coup and he claimed that there will be a toxic Islamist regime at the gates of Europe (Peters, 2016). The Guardian also published an article claiming that Erdogan's repressive policies lead to the coup to conceal the real actors behind the attempt. Alev Scott wrote in her imaginary article that who orchestrated the coup remains unclear (Scott, 2016). Western media even humiliated Turkish people standing up against the coup by referring to them as a herd. However, after the coup attempt failed, Western media emphasized that the failed coup consolidated Erdogan's power. In his article published by The New York Times on July 18, Tim Arango pointed out that Turkey is drifting into the swamp of the Middle East with the failure of the coup attempt (Arango, 2016). Writing for the blog Open Democracy, Cihan Tugal defined the repellence of the coup as a victory of neo-fascism.

\section{FETO Coup and the U.S.}

The U.S. has supported all coups in Turkey so far. The 1980 coup's general Evren was asked by the U.S. Secretary of State Haig why the army was too late. It did not change after the Cold War, in 1997 an elected government was forced to resign with the support of military and the U.S. governments never criticized the military coup (Duran \& Altun, 2016). The U.S. has often criticized Turkey in recent years on the subjects of democracy and human rights. Even though it was not a civil war, the U.S. State Secretary underlined peace and stability when questioned regarding the coup attempt in Turkey instead of highlighting democratic processes and institutions. Everyone witnessed this stance without having a need to open archives as in the Musaddik case or to hear the confessions of actors as in the 1980 coup.

It was also not surprising that the U.S. Secretary of State John Kerry repeated the outdated remark that Turkey must respect democracy, human rights, and fundamental liberties. Kerry also tried to make things difficult for the extradition of FETO leader to Turkey. The U.S. authorities demanded evidence from Turkey and emphasized that they had not received an official request. The coup attempt deepened the issue of trust between the U.S. and Turkey.

The attitude of the U.S. for the coups in the Middle East or somewhere else never changes. As in the case of Egypt, Turkey described the ousting of Morsi as unacceptable, and named the intervention of army as a military coup in contrast to the U.S., which refrained from using the word coup. After overthrowing Morsi, the army called for new elections. Davutoglu underlined that Turkey does support all people of the country reminding that Turkey supports all of Egypt and whatever Egyptians chose, Turkey will be with them. To him it should be a top priority for Egyptians to preserve the gains of the recent revolution stating that it is unacceptable to see politicians arrested. 
While Turkey supported democratically elected government, the U.S. supported the military coup and Sisi. Obama did not use the word coup and suggested that the military had better end a political crisis due to economic difficulties (Hudson, 2013). He called on the Egyptian military to move quickly and responsibly back to a democratically elected civilian government as soon as possible through a transparent process. Obama also said American law forbids aid to countries that remove democratic leaders via a military coup, that's why Obama spoke carefully and did not use the word coup (Jackson, 2013). Even Kerry speculated that Egypt's military was restoring democracy and was asked to intervene by millions of people who were afraid of chaos and violence. As obvious, the U.S. government rejected to describe removal of Morsi as a coup not to cut off its annual aid to Egypt. Kerry reminded that the military did not take over so far and to run the country, there is a civilian government (Chumley, 2013).

Not only politicians but also officials at the White House and State Department refused to characterize incidents in Egypt as a military coup. White House Press Secretary Jay Carney told that they try to determine how to label the issue. According to the law of the Foreign Assistance Act, the U.S. must cut aid to a country that has had a coup. Apparently lawyers told Obama to ignore the law by not asking whether Egypt had a coup or not. Noah Feldman considers that mostly State Department lawyers are hyper-literalists since the law says no aid if there is a coup, but it never orders the administration to inquire whether a coup occurred. According to Feldman this ostrich theory of the law makes no sense. The law forbids aid when a coup occurred that is while the president keeps sending funds, he is violating the law (Feldman, 2013).

\section{Conclusion}

Turkish people regarded the July 15 coup attempt as an invasion and they demonstrated that their country cannot be designed by illegal organizations. FETO with its deep international networks is not an ordinary terrorist organization, so it is not easy to dissolve it in the near future. That's why, extraditing Gulen to Turkey is very important. However, some Western countries do not recognize FETO as an illegal organization and even regard it as a manipulative tool against Turkey. Although FETO bombed the institutions including the parliament, neither European countries nor the U.S. sided with Turkey against FETO. However, Turkey expects its Western allies to fight against FETO, because Turkey sided with its allies after September 11 attacks without hesitating.

\section{References}

Arango, T. (2016, July 17). As Turkey coup unfolded, the whole night felt like doomsday. The New York Times. Retrieved from http://www.nytimes.com

Chumley, C. K. (2013, August 2). John Kerry: Egypt's army was only restoring democracy. The Washington Times. Retrieved from http://www.washingtontimes.com

Duran, B \& Altun, F. (2016, August). The Triumph of Turkish Democracy 15 July Coup Attempt and After. SETA Publications 8 , İstanbul, Turkey.

Feldman, N. (2013, July 26). Obama ignores U.S. law to 1gnore Egypt's coup. The Bloomberg. Retrieved from https://www.bloomberg.com

Hudson, J. (2013, July 4). Obama Administration won't call Egypt's coup a coup. The Foreign Policy. Retrieved from http://thecable.foreignpolicy.com

Jackson, D. (2013, July 8). Obama deeply concerned about Egypt military. The USA Today. Retrieved from http://www.usatoday.com

Oran, B. (2009). Türk Dış Politikası. İstanbul: İletişim Yayınları.

Peters, R. (2016, July 17). Turkey and Erdogan: Here comes the caliphate. The Fox News. Retrieved from http://www.foxnews.com

Scott, A. (2016, July 17). Turkey has defeated a coup and unleashed a violent mob. The Guardian. Retrieved from http://www.theguardian.com 